\title{
THE ORIGIN OF MORAINIC DEPOSITS AND THE CHARACTERISTICS OF GLACIAL EROSION IN THE WESTERN SØR-RONDANE, ANTARGTICA
}

\author{
By R. A. Souchez \\ (Fonds National de la Recherche Scientifique and Service de Géomorphologie de l'Université \\ Libre de Bruxelles, Bruxelles, Belgium)
}

\begin{abstract}
Two types of morainic deposits can be found in western Sør-Rondane mountains: the superglacial morainic ridge the material of which comes from slope evolution, and the hillocky moraine whose origin is related to shear planes in the glacier and therefore subglacial. A hypothesis of the formation of the hillocky moraine is given and the lithological composition of this deposit allows us to deduce the importance of glacial erosion at the level of the ice falls which frequently exist at the beginning of outlet glaciers where they leave the polar ice sheet. On this step, the role of glacier fluctuations is of importance in relation to a special periglacial process: greenhouse frost shattering.
\end{abstract}

RÉsumé. L'origine des dépôts morainiques et les caractéristiques de l'érosion glaciaire dans les Sor-Rondane occidentales, Antarctique. Deux types de dépôts morainiques peuvent être observés dans les Sør-Rondane occidentales: la ride morainique supraglaciaire dont le matériel provient de l'évolution des versants et la moraine de cisaillement d'origine sous-glaciaire en relation avec les surfaces de glissement dans le glacier. Les stades de formation de cette dernière sont analysés à la périphérie de Jenningsbreen. Sa composition lithologique nous permet de conclure à l'importance de l'érosion glaciaire au niveau de la chute de glacier qui existe fréquemment au lieu de naissance des glaciers émissaires lorsqu'ils quittent la calotte polaire. Sur ce verrou-gradin, le rôle des fluctuations glaciaires se révèle important en relation avec un processus périglaciaire particulier: la gélivation par effet de serre.

Zusammenfassung. Die Herkunft von Moränenablagerungen und die Wirkungen der Gletschererosion im westlichen Sør-Rondane, Antarktika. Im westlichen Sør-Rondane-Gebirge können zwei Arten von Moränenablagerungen angetroffen werden: der aufgesetzte Moränenrücken, dessen Material aus der Hangentwicklung stammt, und die hügelartige Moräne, deren Ursprung mit Scherflächen im Gletscher verbunden und daher subglazial ist. Für die Bildung der letzteren wird eine Hypothese entwickelt; ihre lithologische Zusammensetzung erlaubt den Schluss auf die Bedeutung der Gletschererosion auf dem Niveau der Gletscherbrüche, die häufig dort auftreten, wo Auslass-Gletscher aus der Polkalotte austreten. An diesen Stufen spielen Gletscherschwankungen eine wichtige Rolle in Verbindung mit einem besonderen periglazialen Vorgang: der Treibhaus-Frostsprengung.

\section{INTRODUCTION}

With the summer party of the Expédition Antarctique Belgo-Néerlandaise 1964-65 I visited the western part of the Sør-Rondane at $200 \mathrm{~km}$. from the coast in Dronning Maud Land.

This mountain range of about $25^{\circ} \mathrm{km}$. length is limited at the south by the polar ice sheet which gives rise to outlet glaciers crossing the range and subdividing it into different units. For example, in the western part of the Sør-Rondane two important outlet glaciers can be noted: Jenningsbreen and Gunnestadbreen (Fig. I). We examined a third, today almost separated from the polar ice sheet at the south-west of Vengen. By the confluence of these particular glaciers at the north of the mountain range, a piedmont zone is formed which becomes floating at the proximity of the expedition's headquarters, "Base Roi Baudouin" (lat. $70^{\circ} 26^{\prime}$ S., long. $24^{\circ}$ I9' E.), giving rise to a limited ice shelf (van Autenboer and others, I964).

A local glacierization has been observed but is now considerably reduced. Many dry glacial valleys can be found. Their bottom shows a polygonal pattern of well developed ice wedges. Sometimes these valleys are orientated towards the south, i.e. in an opposite direction to the actual drainage. In our opinion a great number of these dry glacial valleys are very ancient features; they represent the traces of the situation before the development of the ice sheet with its outlet glaciers. This will be developed in a paper concerning the glacial history of the western Sør-Rondane. 


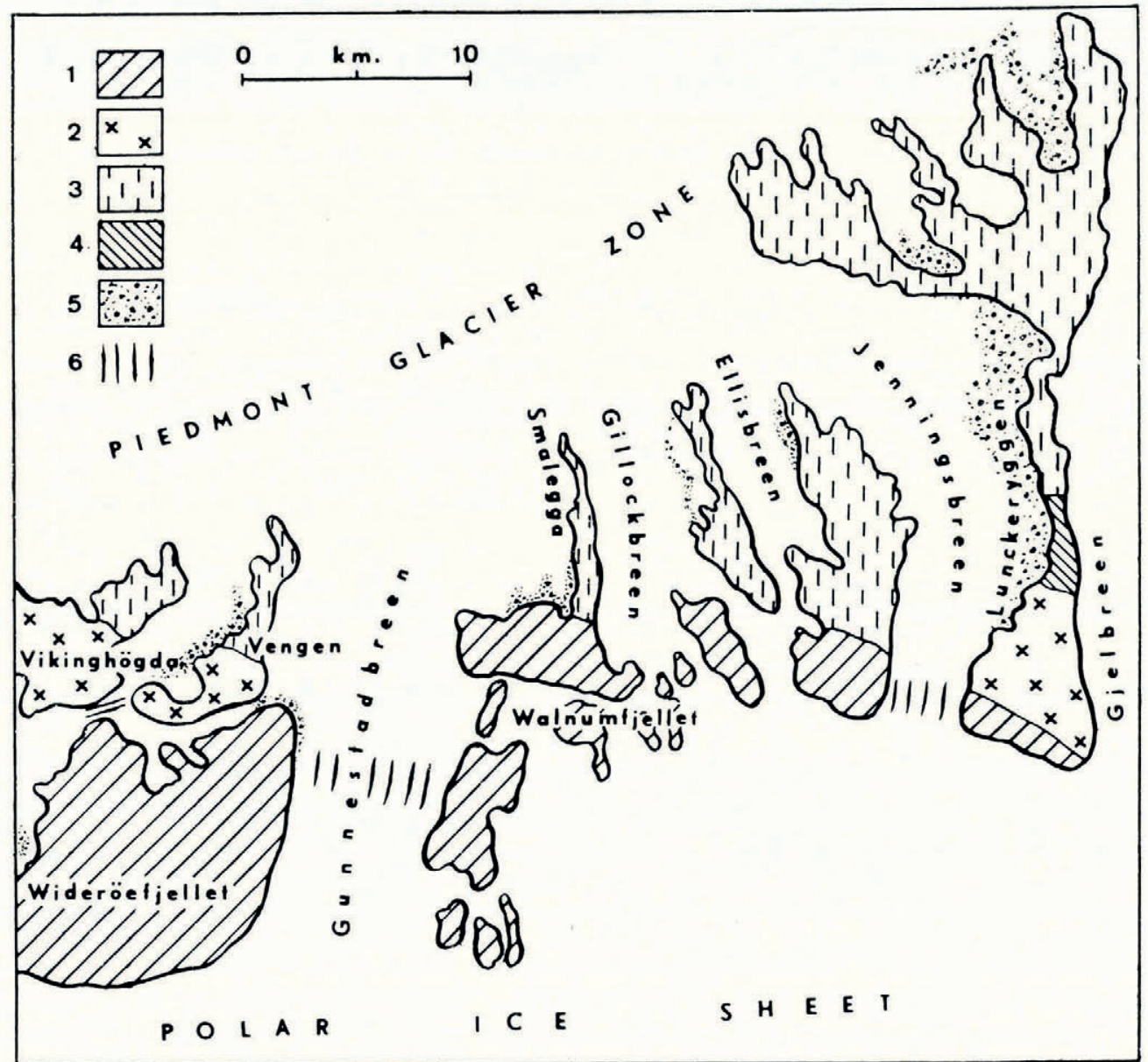

Fig. 1. Map of the western Sor-Rondane.
I. Southern gneisses.
2. Granites.
3. Northern gneisses.
4. Syenites.
5. Morainic deposits.
6. Glacial steps

In this note we are concerned with the origin of the different kinds of morainic deposits and what this means in terms of glacial erosion associated with periglacial processes. For this a brief lithological description is of importance.

\section{Lithological Description}

The western Sør-Rondane, if we except the northern nunataks, are subdivided into two lithological regions: a southern one composed of green homogeneous gabbroic gneisses and a northern one of grey fractured gneisses. Between these two fundamental elements, we find locally complex massifs of granitic and syenitic rocks. So on the left side of Gunnestadbreen and in the vicinity of Vikinghøgda (Fig. I) we can observe grey and rose granites between the 
northern gneisses and the southern gabbroic gneisses. In a similar position syenitic and granitic rocks exist on the right side of Jenningsbreen.

The outlet glaciers present ice falls at the level of the southern gneisses when they leave the ice sheet.

The lithological disposition perpendicular to the direction of displacement of these outlet glaciers, the existence of a great number of crests of lateral moraine with petrographical homogeneity, i.e. composed of rock fragments from one particular lithological area, is very interesting for studying the conditions of glacial erosion at the border of the polar ice sheet.

\section{The Two Types of Morainic Deposits}

Let us take for example the case of the lateral morainic deposits of the outlet glacier called Jenningsbreen (in its southern part). This glacier is partially separated from the polar ice sheet by a small outcrop of southern gneisses but this is a very recent situation. Excluding the debris near the mountain walls, we have found two distinct types of morainic deposits (Souchez, I965):

(a) The hillocky moraine, so called because of its similarity with the description given by Trail (1964) in the Prince Charles Mountains in studying aerial photographs. This hillocky moraine consists of small sub-conical hills or hillocks a few metres high. These hillocks are ice-cored morainic deposits with a small thickness $(20 \mathrm{~cm}$.) of rock fragments fifty centimetres long in maximum. These deposits are almost entirely composed of southern gneisses and this is an important observation. The explanation of this fact will be given below.

(b) The lateral morainic ridge with unpatterned ground and approximately five to ten metres high. On the southern part of Jenningsbreen we found such morainic crests with petrographical homogeneity: one ridge with great blocks more than one metre long of southern gneisses, one of great granitic blocks and a third one mainly composed of syenite. These three moraines begin at the foot of walls where traces of ancient rock falls are abundant and disappear down-glacier (Fig. 2).

Grain-size distributions of fine particles confirm the morphological difference between these two deposits; if we only take into account the particles below $12 \mathrm{~mm}$. in diameter, the hillocky moraine contains at least $\mathrm{I} 7$ per cent of particles with size below $250 \mu$ and 7 per cent with size inferior to Ioo $\mu$ while the lateral morainic ridge with great blocks of southern gneisses only 5 and 2 per cent respectively.

All these observations enable us to make a contrast between the superglacial lateral morainic ridge the material of which comes from slope evolution and the lateral hillocky moraine whose origin is related to shear planes in the glacier and therefore subglacial (Bishop, 1957; Schytt, 196r; Swinzow, 1962; Weertman, I96r).

\section{The Formation of the Hillogky Moraine and the Greenhouse Frost Process}

We can observe today at the border of Jenningsbreen the beginning of formation of hillocky moraine. The debris brought to the proximity of the glacier surface along shear planes introduces a melting of the ice lying immediately above. The occurrence of water near rock fragments has been observed at the end of sunny summer days when the air temperature was $-20^{\circ} \mathrm{C}$. Van Autenboer ( 1962 ) has given evidence of this. This phenomenon is due to the important absorption of the incident energy by the rock, which has a great emission in the infra-red portion of the spectrum, i.e. at a wave-length where ice is opaque. This greenhouse effect is of great morphological importance. The freezing of this water causes a frost-shattering of the blocks; in one day we observed two actual fracturings. So we are able to explain how the same southern gneisses furnish great blocks to the superglacial moraine while only gravels and small fragments constitute the hillocky moraine. When the debris particles are sufficiently 


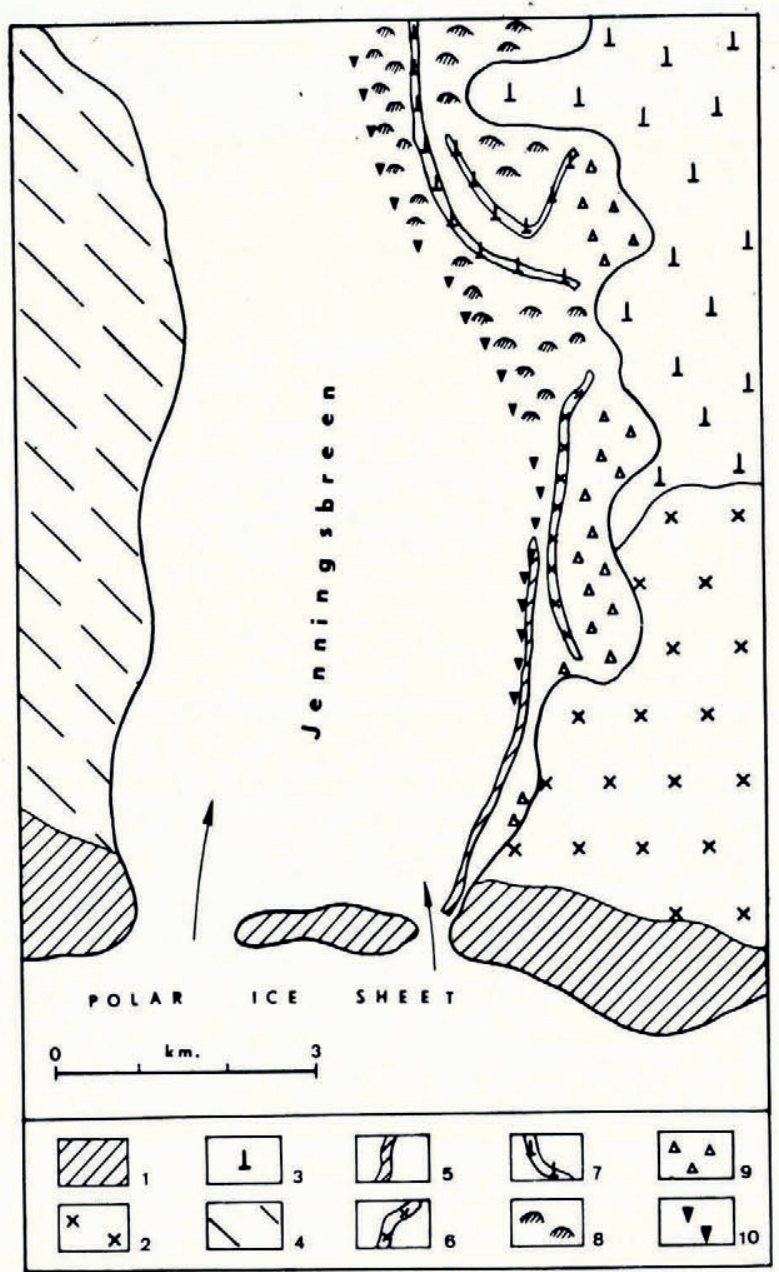

Fig. 2. The morainic field at the beginning of Jenningsbreen.

I. Southern gneisses.

2. Granites.

3. Syenites.

4. Northern gneisses.

5. Superglacial morainic ridge with great blocks of southern gneisses and grey granites.

6. Superglacial morainic ridge with great blocks of granite.

7. Superglacial morainic ridge with blocks of syenite.

8. Hillocky moraine consisting of rock fragments of southern gneiss.

9. Slope and morainic deposits mixed.

IO. Great blocks of southern gneiss-their origin is related to morainic ridge 5

numerous, their insulating effect with respect to the dense, blue ice plays the essential role. The protection exerted against ablation explains the development of the ice-cored hillocks.

A question must be asked: why are these morainic hills wider than the shear zone in the glacier? This fact is due to sliding of rock fragments above the ice when the hillock is sufficiently high. This explains the particular situation at its foot; a great percentage of particles parallel to the line of maximum incline (mean of 70 per cent) and a discontinuity between the debris mantle and the underlying ice (see Fig. 3). 

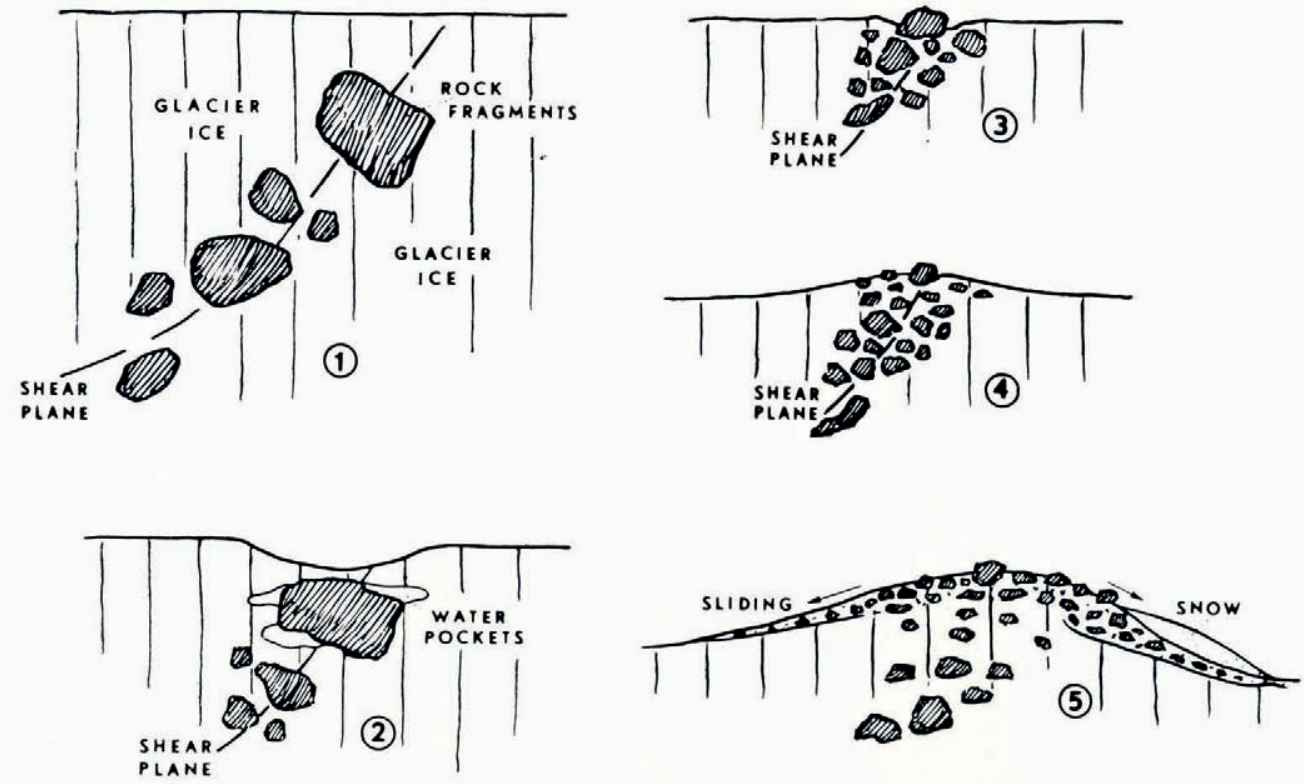

Fig. 3. The formation of a hillock.

I. Lateral shear plane in glacier ice materialized by rock fragments, a certain number of which may be more than one metre long.

2. Greenhouse effect due to the presence of rock fragments near the glacier surface. Pockets of water which on re-freezing cause active frost shattering. A little depression exists in the glacier surface.

3. Concentration of frost-shattered fragments at the surface but not in such quantities to produce protection.

4. High concentration of rock fragments. Protection against ablation due to the insulating effect.

5. Development of the hillock by sliding of the rock fragments on the ice

We can also see in Figure 3 that a shallow depression exists when the blocks are near the ice surface (situation 2) and that a peripheral trench occurs when the top of large fragments emerges from the ice (situation 3). These two microforms are other results of the large absorption effects due to the dark colour of the rock.

The hillocks are grouped parallel to the direction of ice movement and this distribution reflects the existence of the lateral shear planes. The unequal concentration of rock fragments in a shear plane is responsible for the occurrence of hills in place of a small continuous ridge. A similar situation can be noted in the morainic deposits of the outlet glacier south-west of Vengen.

\section{Glacial Erosion and Periglacial Process}

At Lunckeryggen, along the southern part of Jenningsbreen, the hillocky moraines are essentially composed of southern gneisses. This means, in view of the fact that the debris constituting the moraines comes from the glacier bed, that subglacial erosion is particularly active in these rocks.

Two facts can explain this particular situation. First, the slope of the glacier is greater at the level of the step cut in the outcrops of these rocks - we have an ice fall - and secondly this step can be partially free of ice or only covered with a thin layer. The second fact gives rise to a special process of weathering we have discussed: the greenhouse frost shattering. We understand here by this process the particular weathering of rocks under a thin cover of ice. Indeed not only the morainic deposits of subglacial origin are submitted to this process but it can be effective for outcrops of rocks at the level of the ice fall. Elsewhere, on ice-free slopes, the lack of humidity prevents effective frost shattering; the climate is too severe for important subaerial 
denudation without the greenhouse effect. The slopes are practically immunized and the rock falls which have fed the lateral superglacial morainic ridges are inefficient today. The greenhouse frost shattering is and has been active at the level of the step cut in the outcrops of southern gneisses when a thin ice cover is present. The debris provided is evacuated either by ice avalanches or a swelling of the glacier, and is thus incorporated in the glacier bed and thence concentrated in the shear planes. Another fact of importance is thus the effect of glacier fluctuations; frost shattering occurs when the ice has disappeared partially at the level of the step and glacial transportation during subsequent swellings of the glacier. Perhaps, a less cold climate allowed direct frost shattering at the level of the ice fall where humidity has been provided by a small amount of melting of ice.

With these processes we can understand the almost exclusive occurrence of southern gneisses in the hillocky moraine. This enables us to explain the difference between the facts described above and the morainic deposits of Gunnestadbreen. This is a very important outlet glacier where the step at the level of southern gneisses is, and has probably always been, covered with a considerable thickness of ice. Therefore, we do not observe important hillocky moraine of the type described above in the lateral morainic deposits of this glacier. In a severe climate such as that of the Sør-Rondane, glacial erosion requires special conditions to be very active, and among these greenhouse frost shattering.

By mineralogical study of the sand fraction of the hillocky moraines of Jenningsbreen, we have been able, in another paper written in French (Michot and Souchez, 1965), to prove the retreat of the ice fall parallel to itself and thus put forward the notion of glacial headward erosion.

\section{Acknowledgements}

The author wishes to express his gratitude to Professor E. Picciotto, Université Libre de Bruxelles, for the special interest he has shown to him, and to Professor J. Michot, Université Libre de Bruxelles, for valuable information in the field of petrography.

\section{MS. received 22 June 1965}

\section{REFERENGES}

Autenboer, T. van. 1962. Ice mounds and melt phenomena in the Sør-Rondane, Antarctica. Fournal of Glaciology, Vol. 4, No. 33, p. 349-54.

Autenboer, T. van, and others. 1964. Outline of the geology and petrology of the Sør-Rondane mountains, Dronning Maud Land, by T. van Autenboer, J. Michot and E. Picciotto. (In Adie, R. J., ed. Antarctic geology: proceedings of the first international symposium on Antarctic geology, Cape Town, $16-21$ September 1963. Amsterdam, NorthHolland Publishing Co., p. 501-14.)

Bishop, B. C. I957. Shear moraines in the Thule area, north-west Greenland. U.S. Snow, Ice and Permafrost Research Establishment. Research Report 17.

Michot, J., and Souchez, R. 1965. La composition minéralogique des moraines, preuve de l'érosion glaciaire régressive en Antarctique. Comptes Rendus Hebdomadaires des Séances de l'Académie des Sciences (Paris), Tom. 26r, No. 20 , p. $4^{1} 55^{-5} 8$.

Schytt, V. r 961 . Glaciology. II. Blue ice-fields, moraine features and glacier fluctuations. Norwegian-BritishSwedish Antarctic Expedition, 1949-52. Scientific Results, Vol. 4, E, p. 181-204.

Souchez, R. 1965 . Observations sur la composition et la genèse des dépôts morainiques des Sör Rondane occidentales (Antarctique). Comptes Rendus Hebdomadaires des Séances de l'Académie des Sciences (Paris), Tom. 26o, No. 16, p. $4347^{-50}$.

Swinzow, G. K. 1962 . Investigation of shear zones in the ice sheet margin, Thule area, Greenland. Fournal of Glaciology, Vol. 4, No. 32, p. $215^{-29}$.

Trail, D. S. 1964. The glacial geology of the Prince Charles Mountains. (In Adie, R. J., ed. Antarctic geology: proceedings of the first international symposium on Antarctic geology, Cape Town, $16-21$ September 1963. Amsterdam, North-Holland Publishing Co., p. 143-51.)

Weertman, J. 196r. Mechanism for the formation of inner moraines found near the edge of cold ice caps and ice sheets. Journal of Glaciology, Vol. 3, No. 30, p. 965-78. 